\title{
Pemberdayaan Kader Posyandu dalam Pemberian ASI Eksklusif
}

\author{
Nurbaiti $^{1}$, Gustina $^{2}$ \\ ${ }^{1,2}$ Prodi D III Kebidanan STIKes Baiturrahim \\ Email:nbaiti812@gmail.com
}

Submitted : 26/03/2021

Accepted: 08/01/2022

Published: 28/01/2022

\begin{abstract}
Exclusive breastfeeding is the best food for infants breast milk (breast milk) is given for 6 months without other additional food and continued until the age of 2 years, breastfeeding can reduce infant mortality and can increase growth and development in children. at this time there are still many mothers who do not give exclusive breast milk to their babies. Based on data obtained by one of the health centers in Jambi from 111 babies who were given exclusive breast milk 63 babies and who did not give exclusive breastfeeding 28 babies, although most have given exclusive breast milk there are still babies who are not given exclusive breast milk, this can be influenced by the condition of mothers who work outside the home that makes the mother can not breastfeed her baby beside the mother's knowledge of the importance of exclusive breast milk is still not optimal, the busyness of working mothers makes mothers prefer formula milk that is more practical for the baby. Related to the problem, it is necessary to empower cadres so that cadres can play an active role in providing information to mothers who are in the integrated service center area. This service is done to improve the knowledge, understanding, and skills of integrated service center cadres. This activity was carried out in the Working Area of Simpang Kawat Health Center held in March to August 2020, the target in this activity posyandu cadres use the method of lectures, discussions, question and answer with leaflet media and laptop. As a result of this activity increased the knowledge, understanding, and skills of cadres about exclusivebreast milk and will be published in the form of journals to be easily accessed by the community.
\end{abstract}

Keywords: exclusive breast milk, posyandu cadre

\begin{abstract}
Abstrak
Pemberian air susu ibu secara eksklusif merupakan makanan yang terbaik untuk bayi air susu ibu (ASI) di berikan selama 6 bulan tanpa makanan tambahan lainnya dan di lanjutkan hingga umur 2 tahun, pemberian ASI dapat mengurangi angka kematian bayi dan dapat meningkatkan pertumbuhan dan perkembangan pada anak. pada saat ini masih banyak ibu-ibu yang tidak memberikan ASI Eksklusif untuk bayinya. Berdasarkan data yang di proleh salah satu puskesmas di Jambi dari 111 bayi yang di berikan ASI Eksklusif 63 bayi dan yang tidak deberikan asi eksklusif 28 bayi, meskipun sebagian besar sudah memberikan ASI Eksklusif tetapi masih ada bayi yang tidak diberikan ASI Esklusif, hal ini dapat di pengaruhi oleh kondisi ibu yang bekerja di luar rumah yang membuat ibu tidak bisa menyusui bayinya selain itu pengetahuan ibu tentang pentingnya ASI Eksklusif masih belum optimal, kesibukan ibu bekerja membuat ibu lebih memilih susu formula yang lebih praktis untuk bayinya. Berkaitan dengan masalah tersebut maka perlu pemberdayaan kader sehingga kader dapat berperan aktif dalam memberikan informasi kepada ibuibu yang berada di wilayah posyandunya. Pengabdian ini di lakukan untuk meningkatkan pengetahuan, pemahaman dan keterampilan para kader posyandu. Kegiatan ini di lakukan di Wilayah Kerja Puskesmas Simpang Kawat dilaksanakan pada bulan Maret sampai Agustus 2020, sasaran dalam kegiatan ini para kader posyandu menggunakan metode ceramah, diskusi, tanya jawab dengan media leaflet dan lepotop. Hasil dari kegiatan ini meningkatnya pengetahuan, pemahaman dan keterampilan para kader tentang ASI Eksklusif dan akan di pablikasikan dalam bentuk jurnal agar mudah di akses oleh masyarakat.
\end{abstract}

Kata Kunci : ASI eksklusif, kader posyandu 


\section{PENDAHULUAN}

Dunia kembali merumuskan komitmen global dalam bidang kesehatan untuk 15 tahun ke depan. Kali ini diberi nama Sustainable Development Goals (SGDs) yang akan dicapai sampai dengan tahun 2030. SDGs atau tujuan pembangunan berkelanjutan ini hadir menggantikan Millenium Development Goals (MDGs) yang disepakati oleh 198 negara di tahun 2000.(Kemenkes RI, 2016)

Hasil Survei Demografi dan Kesehatan Indonesia (SDKI) tahun 2017 menunjukkan angka kematian neonatus sebesar 15 per 1.000 kelahiran hidup, angka kematian bayi 24 per 1.000 kelahiran hidup, dan angka kematian balita 32 per 1.000 kelahiran hidup. Walaupun telah mengalami penurunan, tetap saja ini masih menjadi masalah yang harus di selesaikan secara keseluruhan. (SDKI, 2017).

Persentase balita sangat pendek dan pendek usia 0-59 bulan di Indonesia tahun 2017 adalah 9,8\% sangat pendek dan 19,8\% pendek. Kondisi ini meningkat dari tahun sebelumnya yaitu persentase balita sangat pendek sebesar $8,57 \%$ dan balita pendek sebesar $18,97 \%$. Hal ini menjadi masalah di Indonesia karena menyebabkan pertumbuhan dan perkembangan anak menjadi terhambat (Kemenkes RI, 2017).

Berdasarkan data yang diperoleh dari Dinas Kesehatan Provinsi Jambi diketahui dari 12 Kabupaten prevelansi gizi kurang dan gizi buruk berdasarkan indikator $\mathrm{BB} / \mathrm{U}$ adalah $17.2 \%$ dan berdasarkan indicator TB/U adalah 20.2\%. Persentase balita sangat pendek dan pendek umur 0-59 bulan menurut kabupaten atau kota tahun 2017 tertinggi yaitu (34.1\%), dan Kabupaten dengan Stunting terendah adalah $(20,1 \%)$. Upaya pencegahan dan penanganan masalah gizi yaitu salah satunya pemberian ASI eksklusif selama 6 bulan penuh dari semenjak lahir tanpa tambahan makanan apapun, pemberian kapsul vitamin A pada balita 6-59 bulan, pemberian tablet tambah darah (TTD) pada ibu hamil dan remaja putri, pemberian makanan tambahan pada ibu hamil KEK dan balita kurus, dan kecukupan energi dan zat gizi balita (Profil Kesehatan Indonesia, 2017).

ASI mengandung kolostrum yang kaya akan antibodi karena mengandung protein untuk daya tahan tubuh dan pembunuh kuman dalam jumlah tinggi sehingga pemberian ASI eksklusif dapat mengurangi risiko kematian pada bayi. Kolostrum berwarna kekuningan dihasilkan pada hari pertama sampai hari ketiga setelah persalinan (Rankin, 2010). Beberapa hasil penelitian menunjukan bahwa pemberian ASI secara eksklusif dapat meningkat pertumbuhan pada anak usia dibawah 2 (dua) tahun, seperti penelitian $\mathrm{Al}$ Rahmad, menyatakan ASI eksklusif sebesar 4,2 kali dapat meningkatkan pertumbuhan pada anak dibandingkan ASI tidak eksklusif.

Posyandu merupakan salah satu bentuk upaya kesehatan bersumberdaya masyarakat (UKBM). Yang dikelola dari, oleh untuk dan bersama masyarakat, guna memperdayakan msyarakat dan memberikan kemudahan kepada masyarakat dalam memproleh pelayanan kesehatan dasar dimana sasaran posyandu adalah bayi, balita, ibu hamil dan ibu menyusi ( Kemenkes 2012). Pergerakan posyandu di monitori oleh kader yang di pilih dari wilayahnya sendiri yang di latih untuk melaksanakan kegiatan posyandu. Kader merupakan salah satu unsur yang memilki peranan penting dalam pelayanan kesehatan seperti mematau pertumbuhan anak,balita dan mengadakan penyuluhan serta memeberikan informasi tentang kesehatan ibu dan anak sehingga masyarakat meengetahui dan dapat mempraktekannya.

Berdasarkan data yang di dapat salah satu puskesmas di kota Jambi dari 111 bayi yang di berikan ASI eksklusif sebanyak 63 bayi dan yang tidak diberikan ASI Esklusif 
sebanyak 28 bayi hal ini dapat di pengaruhi oleh kondisi ibu yang bekerja di luar rumah yang membuat tidak bisa menyusui bayinya selain itu pengetahuan ibu terhadap ASI Eksklusif belum optimal dan pentingnya manfaat ASI eksklusif. Kekurangan pemahaman ibu dan kesibukan ibu bekerja membuat ibu lebih memilih susu formula yang lebih praktis untuk bayinya berdasarkan hal tersebut perlu peningkatan sosialisasi kepada msyarakat tentang pentingnya pemberian ASI eksklusif pada bayi dengan memberikan penyuluhan/informasi kepada kader posyandu yang bertujuan untuk memberikan informasi dan melatih kader posyandu yang ada di wilayah kerja Puskesmas Simpang Kawat Kota Jambi agar kader dapat menginformasikan kepada ibu-ibu yang ada di wilayah tersebut.

\section{TARGET DAN LUARAN}

1. Target

Target dalam pengabdian kepada masyarakat ini adalah

a. Kader

b. Meningkatnya pengetahuan, pemahaman kader $(>95 \%)$

2. Luaran

Hasil atau luaran dalam kegiatan pengabdian ini adalah meningkatnya pengetahuan, pemahaman dan keterampilan para kader posyandu dalam memberikan penyuluhan/ informasi tentang pemberian ASI Esksklusif serta dapat mengoptimalkan peran kader dalam meningkatkan program pemeberian ASI Eksklusif. Dengan adanya penyeluhun tersebut di harapkan ibu-ibu dapat memberikan ASI pada anaknya secara eksklusif. kemudia hasil dari kegiatan ini akan di pablikasikan dalam bentuk jurnal ilmiah nasional sehingga dapat diakses oleh masyarakat..

\section{METODE PELAKSANAAN}

Kegiatan pengbdian masyarakat ini di laksanakan pada bulan Maret-Agustus 2020 dengan dibantu oleh 2 orang mahasiswa D3 Kebidanan Stikes Baiturrahim, sasaran dalam kegiatan ini adalah para kader posyandu yang berjumlah 12 orang metode yang di gunakan ceramah, diskusi, tanya jawab, media yang digunkan lieflet dan leptop dengan tujuan untuk meningkatkan pengetahuan, pemahaman dan keterampilan para kader posyandu dalam memeberikan penyuluhan atau informasi tentang ASI Eksklusif. Tahapan dalam melakukan kegiatan ini adalah : 1). Tahap persiapan dimana tim melakukan pengkajian dan analisa data awal, mengidentifikasi masalah, penyusunan proposal dan satuan acara penyuluhan (SAP), membuat pre-test dan post- test, dan melakukan perizinan serta tertib atministrasi.2) tahap pelaksanaan orientasi tim kegiatan dengan kelompok sasaran, melaksanakan pre-test, memberikan materi tentang pemberian ASI Eksklusif serta melakukan post-test. 3) penyusunan laporan akhir kegiatan.

\section{HASIL DAN PEMBAHASAN}

Kegiatan pengabdian kepada masyarakat ini di hadiri oleh 12 orang kader posyandu, tim kegiatan melakukan pre-test sebelum di berikan materi dan hasil pretes di dapat pengetahuan ibu cukup baik kemudian di lanjutkan dengan memberikan materi/pendidikan kesehatan tentang pemberian ASI Eksklusif agar pengetahuan, dan pemahaaman tentang ASI Eksklusif bertamabah dan mendapatkan informasi terbaru seta meningkatkan keterampilan kader posyandu dalam memberikan informasi atau penyuluhan setelah pemberian materi tersebut kemudian melakukan post-test di dapat pengetahuan ibu meningkat menjadi baik. Hasil dari pelaksaan kegiatan ini adanya peningkatan pengetahuan dan pemahaaman serta keterampilan para kader posyandu Setelah 
kader posyandu mendapatkan pendidikan kesehatan tentang ASI Eksklusif kader posyandu dapat memberikan informasi/penyuluhna kepada ibu-ibu yang datang ke posyandu dan dapat mengoptimalisasikan peran kader posyandu dalam mensukseskan program ASI Ekskluisf. dengan adanya penyeluhun tersebut di harapkan ibu-ibu dapat memberikan ASI pada anaknya secara eksklusif.

Masalah yang di hadapi oleh ibu - ibu adalah banyaknya ibu bekerja pada saat mempunya bayi sehingga ibu tidak bisa memberikan ASI eskklusif dan memilih untuk memberikan susu formula yang lebih praktis. Sebenarnya ibu pekerja juga bisa memberikan ASI Ekskluisf pada bayinya yaitu dengan cara memompa atau memerah ASI kemudian di simpan di prizer dan di berikan nanti pada saat bayi ingin menyusu. Banyak ibu pekerja yang tidak memberikan asi eksklusif dan ada pula ibu pekerja yang memberikan ASI Eksklusif. ASI merupakan makanan yang terbaik untuk bayi ASI mengandung kolostrum yang kaya akan antibodi karena mengandung protein untuk daya tahan tubuh dan pembunuh kuman dalam jumlah tinggi sehingga pemberian ASI eksklusif dapat mengurangi risiko kematian pada bayi dan mencegah terjadinya stanting.

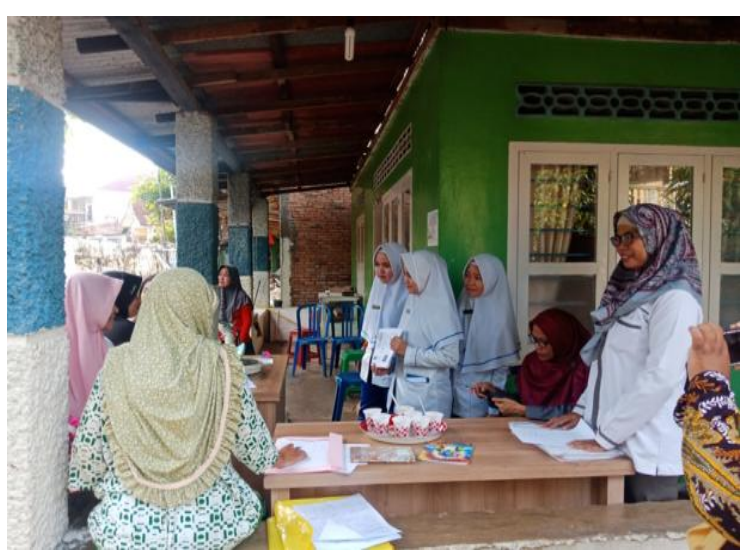

Gamabr.1 kegiatan penyuluhan

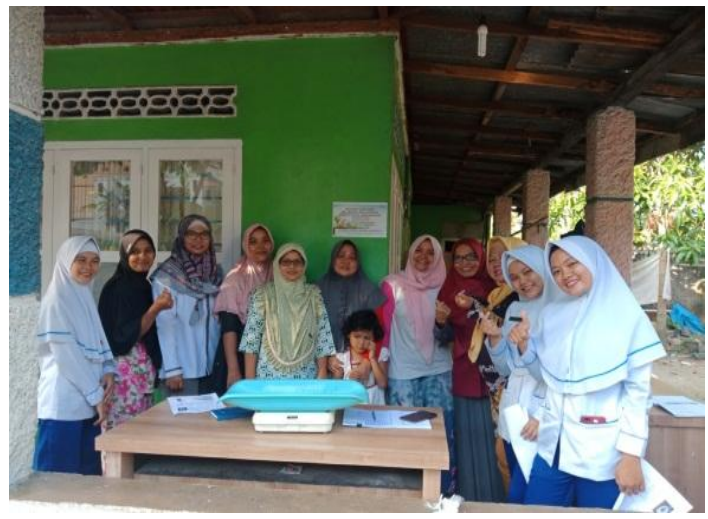

Gambar.2 Kegiatan Penyuluhan

\section{KESIMPULAN DAN SARAN}

1. Kesimpulan

Kegiatan pegabdian kepada masyarakat berupa memberikan materi tentang ASI Eksklusif dapat meningkatkan pengetahuan,pemahaman dan keterampilan para kader posyandu akan pentingnya pemeberian ASI eksklusif guna untuk meningkatkan kesehatan anak. Serta dapat mengoptimalkan, kemampuan dan keterampilan para kader agar dapat memberikan informasi atau penyuluhan kepada ibu- ibu yang ada di wilayah posyandu masing-masing.

\section{Saran}

Agar dapat mengadakan penyuluhan kesehatan tentang ASI Eksklusif secara intensif di wilayah kerja puskesmas simpang kawat kota jambi sehingga pengetahuan dan pemahaman ibu hamil dan menyusui meningkat dengan adanyan penyuluhan tersebut maka dapat meningkatkan kesehatan anak.

\section{UCAPAN TERIMAKASIH}

Tim pengabdian masyarakat mengucapkan terimaksih yang sebesarbesarnya kepada Stikes Baiturrahm atas dana dan fasilitas serta surat izin dalam melakukan pengabdian masyarakat ini dan juga kepada Kepala Puskesmas dan bidan yang telah memberikan izin tempat dan membantu dalam kegiatan pengabdian 
masyarakat ini sehingga kegiatan ini berjalan dengan lancar.

\section{DAFTAR PUSTAKA}

Al Rahmad AH (2016) Malnutrisi pada Balita Pedesaan dengan Perkotaan berdasarkan Karakteristik Keluarga: Data PSG 2015. Idea Nurs J.

Dahlan, Mubin ,Mustika (2013) Hubungan Status Pekerjaan Dengan Pemberian Asi Eksklusif Di Kelurahan Palebon Kecamatan Pedurungan Kota Semarang.Jurnal Kebidanan.vol.2.no.2 tahun 2013

Dinaskesehatan Kota Jambi. (2019) .Jumlah Kunjungan Ibu Hamil di Kota jambiTahun 2018.Jambi

DinasKesehatanProvinsi Jambi (2019). Jumlah Kejadian Stunting di Provinsi Jambi TAHUN 2018.Jambi

Handayani, (2015). Pemeberdayaan kader posyandu dalam program ASI Eksklusif . Jurnal Ilmiah ilmu-ilmu kesehatan vol.XIII No,1,April 2015

Hermina H, Prihatini S. Pengembangan Media Poster dan Strategi Edukasi Gizi untuk Pengguna Posyandu dan Calon Pengantin. Bul Penelit Kesehat. 2015..

Kemenkes RI. 2012. Pusat Promosi Kesehatan Tahun 2012. http://www.depkes.go.id/resources/d ownload/promosi-kesehatan/bukusakuposyandu.pdf [02 Februari 2018]

UNICEF. (2018). The State of The World's Children. New York: Oxford University Press.

Rankin, Stables. 2010. Asuhan Bayi Baru Lahir dan Pemberian ASI Eksklusif. Jakarta 